\title{
Changes in quantity and quality of soil carbon due to the land-use conversion to sugarcane (Saccharum officinarum) plantation in southern Brazil
}

\author{
Ricardo de Oliveira Bordonal ${ }^{\mathrm{a}, \mathrm{b}, *},{\text { Rattan } \mathrm{Lal}^{\mathrm{c}} \text {, Carlos Cesar Ronquim }}^{\mathrm{d}}$, \\ Eduardo Barretto de Figueiredo ${ }^{a}$, João Luís Nunes Carvalho ${ }^{\mathrm{b}}$, Walter Maldonado Jr. ${ }^{\mathrm{a}}$, \\ Débora Marcondes Bastos Pereira Milori ${ }^{\mathrm{e}}$, Newton La Scala Jr. ${ }^{\mathrm{a}}$ \\ a FCAV/UNESP - Department of Exact Sciences, College of Agricultural and Veterinarian Sciences/São Paulo State University, Via de Acesso Prof. Paulo Donato \\ Castellane s/n, 14884-900 Jaboticabal, SP, Brazil \\ b CTBE/CNPEM - Brazilian Bioethanol Science and Technology Laboratory/Brazilian Center for Research in Energy and Materials, Rua Giuseppe Máximo \\ Scolfaro 10000, Polo II de Alta Tecnologia, 13083-100 Campinas, SP, Brazil \\ ${ }^{\mathrm{c}}$ Carbon Management \& Sequestration Center, The Ohio State University, 210 Kottman Hall, 2021 Coffey Rd., Columbus, OH 43210, USA \\ ${ }^{\mathrm{d}}$ CNPM/EMBRAPA - Satellite Monitoring Research Center/Brazilian Agricultural Research Corporation, Fazenda Chapadão,Av. Soldado Passarinho 303, 13070- \\ 115 Campinas, SP, Brazil \\ e CNPDIA/EMBRAPA - Agricultural Instrumentation Center/Brazilian Agricultural Research Corporation, Rua XV de novembro 1452, $13560-970$ São Carlos, SP, \\ Brazil
}

\section{A R T I C L E I N F O}

\section{Article history:}

Received 26 February 2016

Received in revised form 8 February 2017

Accepted 13 February 2017

Available online $\mathrm{xxx}$

\section{Keywords:}

Sugarcane expansion

Ethanol production

Soil management

Soil organic matter

Laser-Induced Fluorescence Spectroscopy

Sustainability

\section{A B S T R A C T}

Soil organic carbon (SOC) plays an important role for soil quality and its conservation is affected by the land-use change (LUC) associated with sugarcane (Saccharum officinarum) expansion. This study was based on the hypothesis that: (i) LUC from perennial crops (e.g., coffee and citrus) and extensive pasture to sugarcane plantation results in depletions of soil carbon (C) stock and its quality; and (ii) transition of annual crops to sugarcane increases soil $\mathrm{C}$ stock and improves its quality. Therefore, the objective of this study was to assess changes in soil C stocks and the humification levels of soil organic matter (SOM) upon conversion of different land uses (coffee, citrus, annual crop and pasture) into sugarcane plantation in the Mococa region, northeast of São Paulo state, southern Brazil. The experiment was conducted within commercial farms and experimental design is comprised of a farming system involving four scenarios of land-use transition to sugarcane (e.g., paired areas). Soil samples were collected to a 1 -m depth $(0-10,10-$ $20,20-60$ and $60-100 \mathrm{~cm}$ ), and the equivalent layers of $0-20$ and $0-100 \mathrm{~cm}$ were obtained for each paired area. SOC decreased in 3 years ranged from 124.5 to $99.8 \mathrm{Mg} \mathrm{Cha}^{-1}$ for the $0-100 \mathrm{~cm}$ layer following the conversion of coffee to sugarcane. Conversion of citrus to sugarcane depleted soil C stock from 147.7 to $113.1 \mathrm{Mg} \mathrm{Cha}^{-1}$ for the $0-100 \mathrm{~cm}$ layer after a 4 -year period. Conversion of pasture into sugarcane was comparatively less adverse in terms of soil C stocks, with depletion only for the $0-20 \mathrm{~cm}$ layer from 30.3 to $17.0 \mathrm{MgCha}^{-1}$ in 8 years. Regarding the conversion from annual crop to sugarcane, there was no difference in soil C stock among land uses at any soil depths. Laser-Induced Fluorescence Spectroscopy (LIFS) showed a high stage of humification of SOM with increase in the magnitude of depletion of soil C stock, and vice versa. Increases in humification stages of SOM were observed from the top to the deepest layers for most of the land-use systems. Overall, conversions of perennial tree crops (e.g., coffee and citrus) into sugarcane increased the humification levels of SOM in sub-soil, except when sugarcane replaced pasture. The latter had lower humification of SOM in the surface layers of soil because of intensive tillage associated with sugarcane planting operations. Thus, the short-term maintenance of straw had a minor impact in improving soil $\mathrm{C}$ accumulation as well as reversing the increased oxidation level of SOM induced by sugarcane expansion. Further, our study suggests the need of assessing the

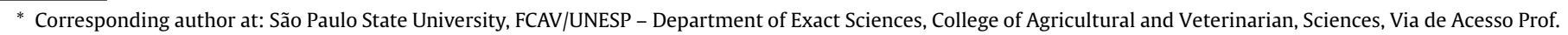
Paulo Donato Castellane s/n, Jaboticabal 14884-900, Brazil.

E-mail addresses: rbordonal@yahoo.com.br, rbordonal@msn.com (R.d.O. Bordonal).
} 
impacts of LUC on soil C budget to deep sub-soil layers in agricultural systems. Finally, the data indicate that expansion of sugarcane over coffee and citrus agrosystems may impact the sustainability of ethanol production because of LUC-induced depletion of soil C stock and degradation of soil quality.

(c) 2017 Elsevier B.V. All rights reserved.

\section{Introduction}

Assessment of anthropogenic carbon dioxide $\left(\mathrm{CO}_{2}\right)$ emissions and their redistribution in the global carbon (C) budget (e.g., atmosphere, ocean, and terrestrial biosphere) is important to development of strategies to mitigate greenhouse gas (GHG) emissions. The global $\mathrm{C}$ budget averaged over the last decade (2005-2014) was 91\% caused by fossil fuels and industry $\left(9.0 \pm 0.5 \mathrm{PgC}\right.$ year $\left.^{-1}\right)$, and $9 \%$ by land-use change $(0.9 \pm 0.5 \mathrm{PgC}$ year $\left.{ }^{-1}\right)$. The growth rate in atmospheric carbon dioxide $\left(\mathrm{CO}_{2}\right)$ increased to $4.4 \pm 0.1 \mathrm{PgC}$ year $^{-1}$ for the same period, and both ocean $\left(2.6 \pm 0.5 \mathrm{Pg} C\right.$ year $\left.^{-1}\right)$ and land $\left(3.0 \pm 0.8 \mathrm{Pg}\left(\right.\right.$ year $\left.^{-1}\right) \mathrm{CO}_{2}$ sinks increased approximately similar to that of the increase in atmosphere (Le Quéré et al., 2015). Soil organic carbon (SOC) is a large component of the global $\mathrm{C}$ cycle (Lal, 2004a) and its management affects the atmospheric $\mathrm{CO}_{2}$ levels (Lal, 2004b).

A long-term solution in developing alternatives to fossil fuel has been the renewable energy sources, such as the Brazilian sugarcane (Saccharum officinarium) ethanol (Goldemberg, 2007), which also accelerates the expansion of new agricultural lands. Brazil is a leading producer of sugarcane ethanol with a total cultivated area of around 9.1 million hectare (Mha) in the 2015/ 2016 season, and São Paulo State accounts for over 52\% of the total area (5). The sugarcane ethanol production is projected to increase from the current 21-61.6 billion liters by 2021, and an additional 6.4 Mha of sugarcane area would be required to meet the demand (Goldemberg et al., 2014). Despite numerous strategic advantages of sugarcane ethanol through replacement of fossil fuels (Börjesson, 2009; Seabra et al., 2011), the rapid expansion of sugarcane plantation has raised questions regarding its sustainability (Lapola et al., 2010).

The land-use change (LUC) and agricultural sectors have been the major source of GHG emissions in 2005, being responsible for $\sim 80 \%$ of total emissions in Brazil (MCTI, 2010). However, the recent report from the Brazilian government presented a decrease of $85 \%$ in GHG emissions from the LUC sector between 2005 and 2012 (MCTI, 2014), which is mostly attributed to the reduction in deforestation in Amazonia region (Nepstad et al., 2014). Assessing the impact of LUC of about 4 Mha during 2005-2010 in southcentral Brazil, Adami et al. (2012) observed that 95\% of sugarcane expansion has occurred on pastures (69.7\%), annual crops (25\%) and citrus (1.3\%).

The potential benefits of biofuels to offset $\mathrm{C}$ emissions depend strongly on the LUC triggered by the expansion of bioenergy crops (Lapola et al., 2010). Biofuels can create a "carbon debt" and reduce the $C$ savings achieved by replacing fossil fuels, depending on how they are produced (Fargione et al., 2008; Searchinger et al., 2008; Mello et al., 2014). Changes in soil C stocks are usually not accounted for in any life cycle analysis (LCA) of sugarcane plantation, but have a large impact on the results (AndersonTeixeira et al., 2009). Thus, inclusion of the LUC-induced emissions into GHG balance of sugarcane cultivation should be a high priority in the ethanol production chain (Bordonal et al., 2015).

An important management issue is the knowledge about the extent of soil $\mathrm{C}$ dynamics when diverse agricultural systems are converted into sugarcane plantation. Regional changes on coverage and land-use driven by sugarcane expansion may affect the biogeochemical cycles, including soil C stocks and GHG emissions (Don et al., 2012; Mello et al., 2014). Soil can be a sink or source of C depending on the LUC and management practices (Batlle-Bayer et al., 2010), and its quality is an important indicator for assessing the environmental sustainability of widely expanded sugarcane plantation in Brazil (Cherubin et al., 2015).

Previous studies under tropical soils in central-southern Brazil have shown that conversions from native vegetation to sugarcane and from pasture to sugarcane deplete the soil C stocks (Mello et al., 2014; Franco et al., 2015). On the other hand, higher C stocks have been observed upon conversion of cropland to sugarcane (Mello et al., 2014). Although the effects of LUC on soil C stocks have been reported by recent publications, the magnitude of

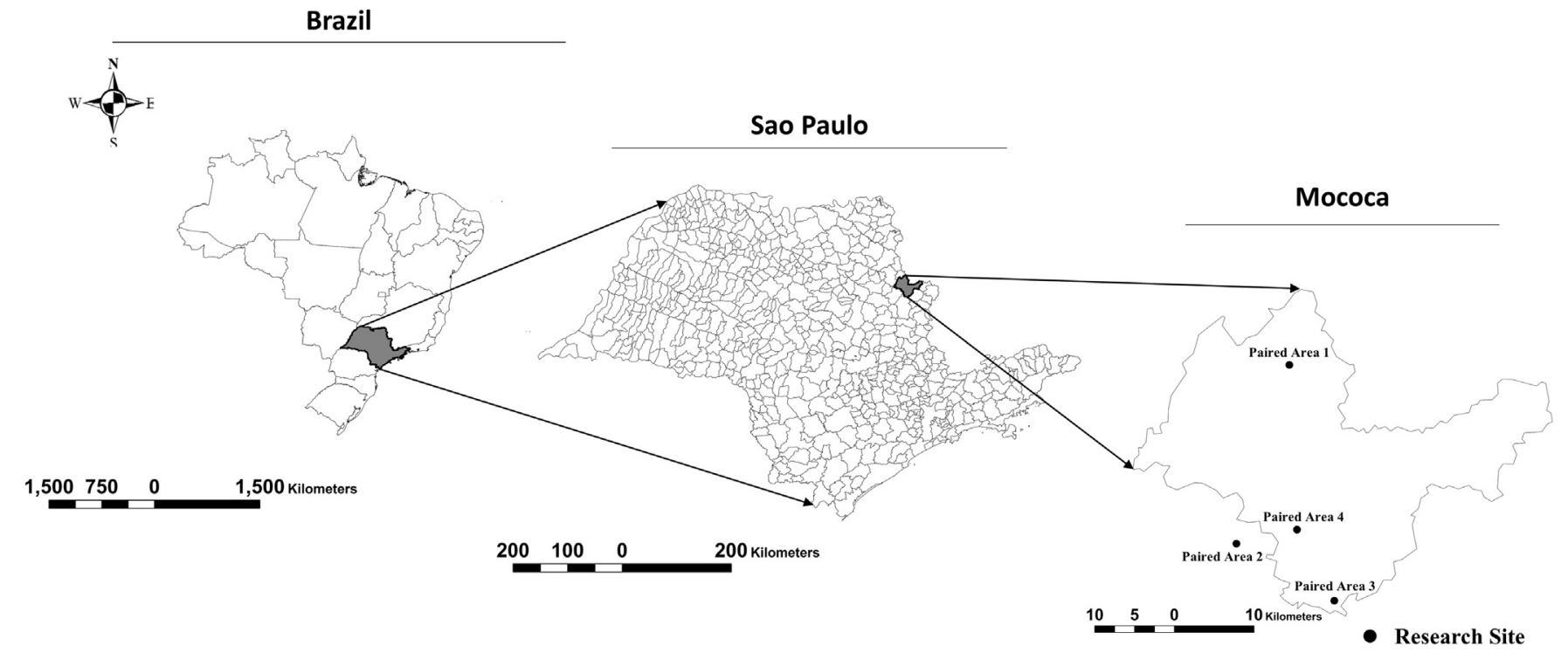

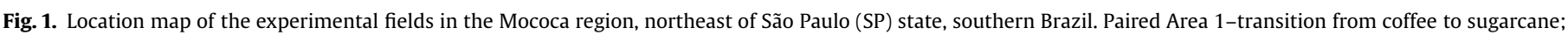
Paired Area 2-transition from citrus to sugarcane; Paired Area 3-transition from annual crop to sugarcane; and Paired Area 4-transition from pasture to sugarcane. 
quantitative and qualitative changes in SOC storage among contrasting land uses and management practices has not been widely studied for tropical soils under sugarcane expansion (Franco et al., 2015).

Storage and humification stage of SOC are considered essential to evaluating soil quality, and to determining qualitative and quantitative changes related to different land uses and management systems (Martins et al., 2015). Several spectroscopic techniques have been used to assess the impact of land use and management systems on the quality of soil organic matter (SOM) in tropical and subtropical regions of Brazil (Dieckow et al., 2009; Tivet et al., 2013). Laser-Induced Fluorescence Spectroscopy (LIFS) is a rapid, efficient and precise technique for the characterization of SOM (Santos et al., 2015), and for the assessment of its humification level in bulk soil samples from different depths (Milori et al., 2006; Segnini et al., 2013; Tivet et al., 2013). This technique can measure $C$ content in a complex or rigid structure, such as aromatic and quinone groups in the bulk soil samples, in which higher fluorescence intensities are associated with greater humification levels (Martins et al., 2015).

Therefore, field experiments are crucial to up scale the agrosystems responses to the impacts of LUC on C cycle at regional and national scales. The need for studies investigating quantitative changes in C stocks as well as the quality of SOM is an important step towards a better comprehension of the SOC stock responses to LUC and management practices associated with sugarcane expansion. The data of these experiments are essential for supporting public policies and decision making related to the land-use and management. This study is based on the hypothesis that: (i) LUC from perennial crops (e.g., coffee and citrus) and extensive pastures to sugarcane plantation results in depletions of soil C stock and its quality; and (ii) conversion of annual crops to sugarcane increases soil $C$ stock and improves its quality. Thus, the objective of this study was to assess the changes in soil C stocks and in the humification index of SOM upon conversion of diverse land uses (coffee, citrus, annual crops and pasture) into sugarcane

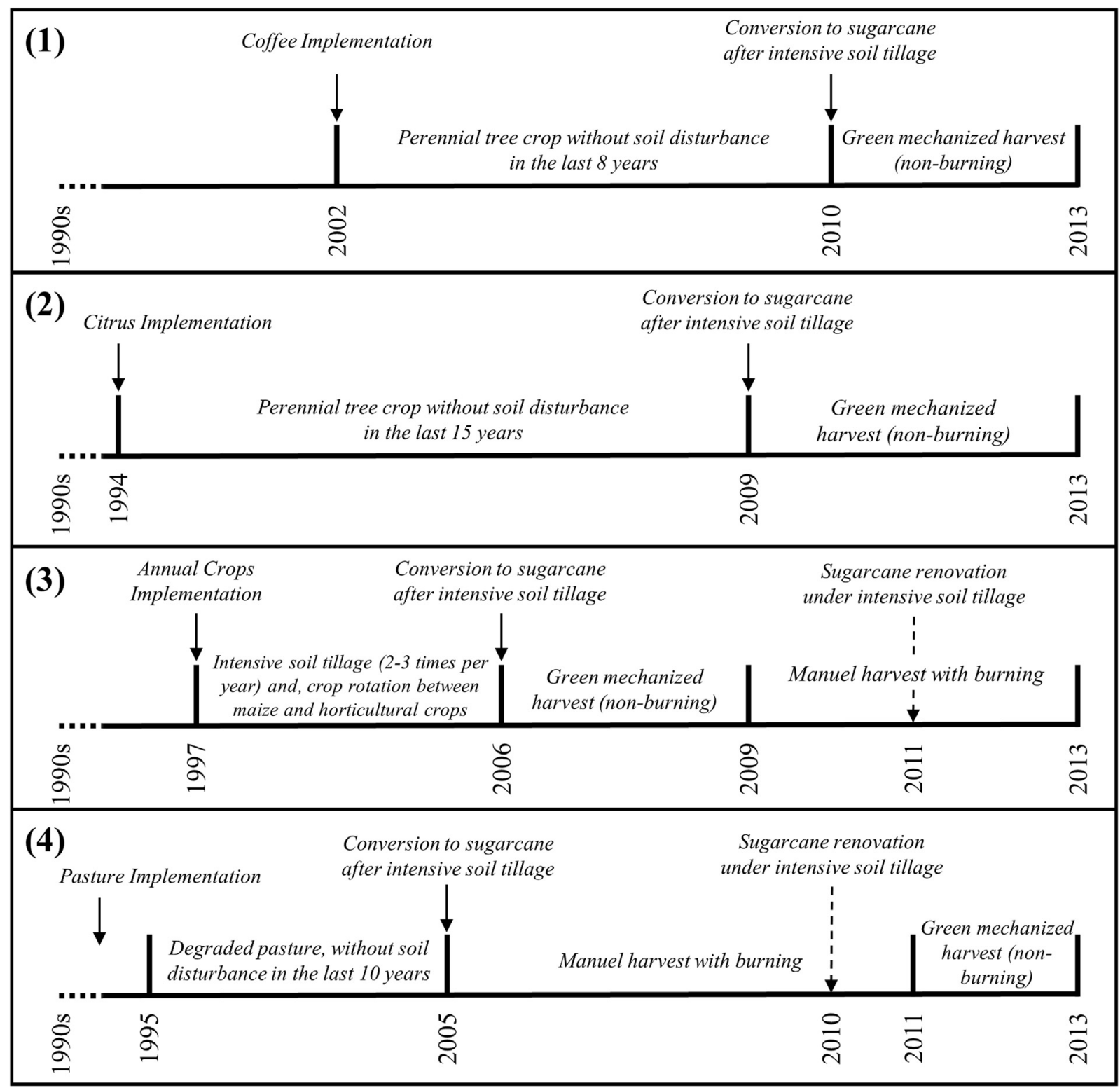

Fig. 2. Schematization of the chronosequence of land use and changes in the four paired areas: (1) coffee to sugarcane; (2) citrus to sugarcane; (3) annual crop to sugarcane; and (4) pasture to sugarcane. Soil sampling was performed on 22 April 2013. 
plantation in southern Brazil. The objective was also to identify the LUC that can be prioritized to ensure the sustainability of sugarcane expansion in Brazil.

\section{Materials and methods}

\subsection{Description of the study areas}

The experimental sites are located in the Mococa region, northeast of São Paulo (SP) state, southern Brazil (Fig. 1). The field experiment was carried out within commercial farms, and therefore, was not set up for scientific purposes. It is comprised of four paired areas: Paired area 1 -coffee $\left(21^{\circ} 21^{\prime} 01^{\prime \prime} \mathrm{S}-47^{\circ} 04^{\prime} 17^{\prime \prime} \mathrm{W}\right)$ and sugarcane $\left(21^{\circ} 20^{\prime} 52^{\prime \prime} \mathrm{S}-47^{\circ} 05^{\prime} 15^{\prime \prime} \mathrm{W}\right)$; Paired area 2 -citrus $\left(21^{\circ} 33^{\prime} 08^{\prime \prime} \mathrm{S}-47^{\circ} 07^{\prime} 52^{\prime \prime} \mathrm{W}\right)$ and sugarcane $\left(21^{\circ} 32^{\prime} 59^{\prime \prime} \mathrm{S}-\right.$ $\left.47^{\circ} 08^{\prime} 11^{\prime \prime} \mathrm{W}\right)$; $\quad$ Paired area 3-annual crops $\left(21^{\circ} 37^{\prime} 30^{\prime \prime} \mathrm{S}-\right.$ $\left.47^{\circ} 01^{\prime} 22^{\prime \prime} \mathrm{W}\right)$ and sugarcane $\left(21^{\circ} 37^{\prime} 00^{\prime} \mathrm{S}-47^{\circ} 01^{\prime} 14^{\prime \prime} \mathrm{W}\right)$; and Paired area 4-pasture $\left(21^{\circ} 32^{\prime} 11^{\prime \prime} \mathrm{S}-47^{\circ} 03^{\prime} 56^{\prime \prime} \mathrm{W}\right)$ and sugarcane $\left(21^{\circ} 32^{\prime} 11^{\prime \prime} \mathrm{S}-47^{\circ} 03^{\prime} 46^{\prime \prime} \mathrm{W}\right)$. The climatic classification of the region is B1 $\mathrm{rB}^{\prime} 4 \mathrm{a}^{\prime}$ (Thornthwaite, 1948), which is tropical moist with an average annual temperature of $21^{\circ} \mathrm{C}$. The mean annual precipitation is approximately $1500 \mathrm{~mm}$ and most rainfall is received between October and March with a relatively dry period between April and September. The native vegetation prior to growing the agricultural crops in the Mococa region is comprised of a transition of Cerrado biome, with a species-rich dense vegetation of shrubs and trees, being generically known as "cerrado sensu-stricto" (Roscoe et al., 2000) and normally associated with transitions of seasonal semi-deciduous forests (Oliveira Filho and Ratter, 2000).

\subsection{Experimental design and treatments}

The paired-site experimental design is comprised of a farming system involving four situations of land-use conversion to sugarcane (e.g., paired areas), which were chosen as independent and are not comparable among themselves. Each paired area in the chronosequence approach was selected to be as similar as possible in all other attributes (e.g., climate, soil), but differing only in land uses. Fig. 2 summarizes major characteristics of paired comparison over time since the initial LUC and the historic land-use and management for each agricultural system of this specific chronosequence approach. The historic land-use and management for the agricultural systems prior to conversion into sugarcane is as follows:

1) Coffee - Coffea arabica L. cv. Catuaí was established at $3.5 \times 1 \mathrm{~m}$ spacing in 2002 after intensive soil tillage. Weed control in the inter-row zone was achieved for 8 years by using glyphosate without soil disturbance. In 2010, part of the area was converted into sugarcane;

2) Citrus -Citrus sinensis L. Osbeck was established at $6 \times 4 \mathrm{~m}$ spacing in 1994 after intensive soil tillage. Soil in the inter-row was covered with grass vegetation (Brachiaria spp.), which was mowed annually for 15 years without any soil disturbance. In 2009, part of this area was converted into sugarcane;

3) Annual crops - maize (Zea mays L.) was cultivated during the summer seasons and in rotation with vegetables such as onion (Allium cepa L.), sugar beet (Beta vulgaris) and carrot (Daucus carota). This area was under crop cultivation with intensive soil tillage (e.g., 2-3 times per year) for the past 9 years. In 2006, an adjacent area under the same land-use and management was converted into sugarcane;

4) Pasture-Brachiaria decumbens (Brachiaria decumbens stapf) was grown for more than 10 years. The site was a degraded pasture without management (e.g., fertilizers application) or any soil disturbance for the last 10 years. In 2005, part of the area was converted into sugarcane.

\subsection{Estimation of dry biomass and C-input by each LU system}

Crop residues input is also an important determinant of soil $\mathrm{C}$ dynamics associated with LUC induced by sugarcane expansion. The cropping systems generate large amounts of crop residues that are returned to soil annually in the form of new branches, leaves, twigs, straw, rhizomes and roots. Plant species can affect the magnitude of SOM dynamics in different ways because of variation in their quantity and quality of above- and belowground crop residues inputs. Therefore, estimations of the total inputs of aboveand belowground crop residues (on dry basis; $\mathrm{Mg} \mathrm{ha}^{-1} \mathrm{year}^{-1}$ ) as well as the cumulative biomass-C inputs $\left(\mathrm{MgCha}^{-1}\right)$ were obtained from literature for all crops of the paired areas. The biomass-C input of each crop was estimated by multiplying the dry biomass (above- and belowground) by its respective $C$ content, and

Table 1

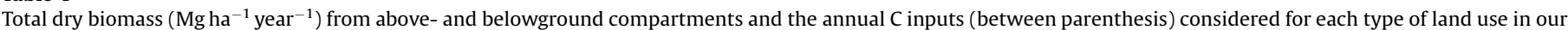

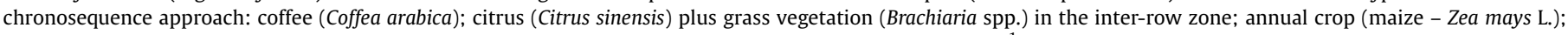

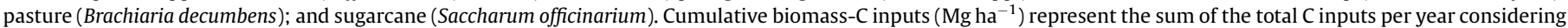
the entire timeframe for each paired-site.

\begin{tabular}{|c|c|c|c|c|c|c|c|c|c|c|}
\hline \multirow{3}{*}{$\begin{array}{l}\text { Compartments } \\
\left(\mathrm{Mg} \mathrm{ha}^{-1} \text { year }^{-1}\right)\end{array}$} & \multicolumn{2}{|c|}{ Paired Area 1} & \multicolumn{2}{|l|}{ Paired Area 2} & \multicolumn{3}{|c|}{ Paired Area 3} & \multicolumn{3}{|c|}{ Paired Area 4} \\
\hline & \multirow[t]{2}{*}{ Coffee $^{\mathrm{b}, \mathrm{a}}$} & \multirow{2}{*}{$\begin{array}{l}\text { Sugarcane }^{c} \\
\text { GH }\end{array}$} & \multirow[t]{2}{*}{ Citrus $^{\mathrm{d}, \mathrm{a}} / \mathrm{Grass}^{\mathrm{e}, \mathrm{a}}$} & \multirow{2}{*}{$\begin{array}{l}\text { Sugarcane }^{c} \\
\text { GH }\end{array}$} & \multirow{2}{*}{$\begin{array}{l}\text { Annual } \\
\text { crop }^{c}\end{array}$} & \multicolumn{2}{|c|}{ Sugarcane ${ }^{c}$} & \multirow[t]{2}{*}{ Pasture $^{\mathrm{e}, \mathrm{a}}$} & \multicolumn{2}{|c|}{ Sugarcane ${ }^{c}$} \\
\hline & & & & & & $\mathrm{BH}$ & $\mathrm{GH}$ & & $\mathrm{BH}$ & $\mathrm{GH}$ \\
\hline Aboveground & $4.5(2.3)$ & $12.6(5.5)$ & $3.5(1.8) / 1.8(0.9)$ & $12.6(5.5)$ & $8.5(3.6)$ & - & $12.6(5.5)$ & $1.8(0.9)$ & - & $12.6(5.5)$ \\
\hline Belowground & $4.3(2.1)$ & $5.6(1.9)$ & $3.0(1.5) / 2.9(1.4)$ & $5.6(1.9)$ & $2.4(0.9)$ & $5.6(1.9)$ & $5.6(1.9)$ & $2.9(1.4)$ & $5.6(1.9)$ & $5.6(1.9)$ \\
\hline Total dry biomass & $8.8(4.4)$ & $18.2(7.4)$ & $6.5(3.3) / 4.7(2.3)$ & $18.2(7.4)$ & $10.9(4.5)$ & $5.6(1.9)$ & $18.2(7.4)$ & $4.7(2.3)$ & $5.6(1.9)$ & $18.2(7.4)$ \\
\hline Cumulative biomass- $\mathrm{C}$ inputs ( $\left.\mathrm{MgCha} \mathrm{Ch}^{-1}\right)$ & 35.2 & 22.2 & $49.5 / 34.4$ & 29.6 & 40.5 & \multicolumn{2}{|c|}{$29.8^{\mathrm{f}}$} & 23 & \multicolumn{2}{|c|}{$26.2^{\mathrm{g}}$} \\
\hline
\end{tabular}

$\mathrm{BH}$ - pre-harvest burning (burned residues) and GH - green harvest without burning.

a A default $C$ fraction of $50 \%$ has been assumed to convert biomass dry matter into $C$ content (Ronquim, 2007).

b The data of above- and belowground biomass were acquired from Campanha et al. (2007) and Defrenet et al. (2016), respectively.

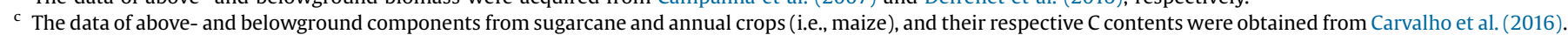

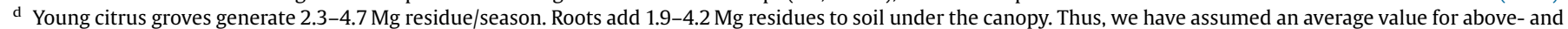
belowground biomass (Krishna, 2013).

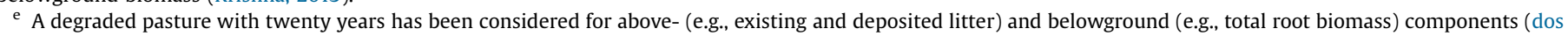
Santos et al., 2007). In citrus area, the same C inputs have been assumed for soil cover with grass vegetation (Brachiaria spp.) in the inter-row zone.

${ }^{\mathrm{f}}$ Sugarcane under green mechanized harvest (non-burning) during 3 years and manual harvest with burning for 4 years.

g Sugarcane under manual harvest with burning during 6 years and green mechanized harvest (non-burning) for 2 years. 
therefore the cumulative $C$ inputs were calculated as the sum of annual $C$ input considering the specific period of each paired site. Details of the total dry biomass (above- and belowground) production, and the respective $C$ inputs contributed by each crop in the paired sites are summarized in Table 1.

\subsection{Soil type and physical attributes of each paired area}

With focus on the process of LUC (i.e., coffee, citrus, annual crop and pasture) to sugarcane plantation, the selection criteria were based on the availability of: information on historic land-use, reference or baseline areas with similar edaphoclimatic conditions (i.e., topography, weather and soil type) and, of sugarcane plantation in close proximity. A summary of the soil characterization (soil type, bulk density and particle size fraction) for each paired area is shown in Table 2.

\subsection{Soil sampling and analysis}

Soil samples were collected in April 2013 for four paired areas, representing land-use conversion of: (1) coffee, (2) citrus, (3) annual crops and (4) pasture into sugarcane plantation. Composite soil samples were obtained randomly from between the crop rows at five spatial replicates within each area and at four soil depths $(0-$ $10,10-20,20-60$ and $60-100 \mathrm{~cm}$ ), with a total of 20 samples per area or 40 samples for each comparison pair. Soil samples were analyzed for total $C$ content, soil bulk density $\left(\rho_{\mathrm{b}}\right)$ and humification index $\left(\mathrm{H}_{\text {LIFS }}\right)$ of SOM. Soil sampling, sample preparation, and storage pending analyses followed the protocol established by EMBRAPA (1997).

Soil $\rho_{\mathrm{b}}$ was determined on undisturbed samples collected by a core sampler with core size of $5.0 \mathrm{~cm}$ in internal diameter and
$4.0 \mathrm{~cm}$ in height (EMBRAPA, 1997). Soil in undisturbed core samples was composited for evaluation of the dry soil weight $\left(105^{\circ} \mathrm{C}\right)$. After air-drying and gentle grinding, soil samples were sieved through a $2-\mathrm{mm}$ sieve. $10 \mathrm{~g}$ of each sample was finely ground and sieved through a $0.25-\mathrm{mm}$ sieve for measurements in duplicate. Soil $\rho_{\mathrm{b}}$ was calculated by dividing the dry weight by the core volume (Blake and Hartge, 1986), and the total C content was determined by the dry combustion method using a Carbon Analyzer-LECO model CR 41 (Nelson and Sommers, 1982).

\subsection{Soil C stock calculation}

In addition to the total $\mathrm{C}$ content, soil $\mathrm{C}$ stocks were also calculated for all soil depths $(0-10,10-20,20-60$ and $60-100 \mathrm{~cm})$ by multiplying the $C$ content by the soil $\rho_{\mathrm{b}}$ and the layer thickness. Stocks of $C$ for the $0-20$ and $0-100 \mathrm{~cm}$ layers were calculated as the sum of the stocks for each sampled depth. As samples were collected from fixed layers, soil $\mathrm{C}$ stocks were also computed on equal mass basis to account for variations in $\rho_{\mathrm{b}}$ after LUC (Ellert and Bettany, 1995). To calculate the $C$ stocks for an equivalent soil mass, the depth of the sugarcane areas was adjusted, i.e., the depth of the sugarcane areas containing the same soil mass as the corresponding layer in area before LUC (e.g., baseline areas: coffee, citrus, annual crop and pasture). Detailed information regarding the calculation of soil $\mathrm{C}$ stocks for an equivalent soil mass is given by Carvalho et al. (2009).

\subsection{Annual rates of soil C loss/accumulation}

The annual rates of $C$ loss or gains associated with LUC of diverse agricultural systems (e.g., coffee, citrus, annual crop and pasture) into sugarcane plantation were calculated for the $0-20$

Table 2

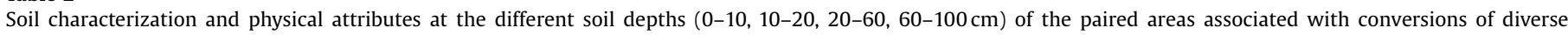

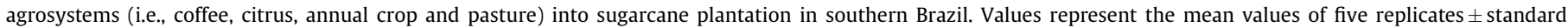
deviation.

\begin{tabular}{|c|c|c|c|c|c|c|c|c|}
\hline \multirow[t]{2}{*}{ Description } & \multicolumn{2}{|l|}{ Paired Area 1} & \multicolumn{2}{|l|}{ Paired Area 2} & \multicolumn{2}{|l|}{ Paired Area 3} & \multicolumn{2}{|l|}{ Paired Area 4} \\
\hline & Coffee & Sugarcane & Citrus & Sugarcane & Annual crops & Sugarcane & Pasture & Sugarcane \\
\hline \multirow{4}{*}{$\begin{array}{l}\text { Soil } \\
\text { classification }^{\mathrm{a}}\end{array}$} & Latossolos (Br. & Latossolos (Br. & Argissolos (Br. & Argissolos (Br. & Latossolos (Br. & Latossolos (Br. & Argissolos (Br. & Argissolos (Br. \\
\hline & (lass.) & (lass.) & (lass.) & Class.) & Class.) & Class.) & Class.) & (lass.) \\
\hline & Ferralsols (FAO) & Ferralsols (FAO) & Luvisols (FAO) & Luvisols (FAO) & Ferralsols (FAO) & Ferralsols (FAO) & Luvisols (FAO) & Luvisols (FAO) \\
\hline & Oxisols (USDA) & Oxisols (USDA) & Ultisols (USDA) & Ultisols (USDA) & Oxisols (USDA) & Oxisols (USDA) & Ultisols (USDA) & Ultisols (USDA) \\
\hline Parent material & Sandstone & Sandstone & Sandstone & Sandstone & Granite & Granite & Sandstone & Sandstone \\
\hline \multicolumn{9}{|c|}{ Soil bulk density $\left(\mathrm{Mg} \mathrm{m}^{-3}\right)$} \\
\hline $0-10 \mathrm{~cm}$ & $1.36 \pm 0.15$ & $1.30 \pm 0.06$ & $1.27 \pm 0.12$ & $1.20 \pm 0.15$ & $1.30 \pm 0.12$ & $1.24 \pm 0.14$ & $1.34 \pm 0.08$ & $1.34 \pm 0.10$ \\
\hline $10-20 \mathrm{~cm}$ & $1.58 \pm 0.07$ & $1.34 \pm 0.06$ & $1.30 \pm 0.04$ & $1.32 \pm 0.14$ & $1.44 \pm 0.07$ & $1.32 \pm 0.07$ & $1.40 \pm 0.08$ & $1.43 \pm 0.12$ \\
\hline $20-60 \mathrm{~cm}$ & $1.41 \pm 0.09$ & $1.55 \pm 0.08$ & $1.17 \pm 0.04$ & $1.32 \pm 0.14$ & $1.51 \pm 0.11$ & $1.45 \pm 0.06$ & $1.45 \pm 0.04$ & $1.43 \pm 0.15$ \\
\hline $60-100 \mathrm{~cm}$ & $1.31 \pm 0.09$ & $1.46 \pm 0.19$ & $1.24 \pm 0.08$ & $1.01 \pm 0.19$ & $1.32 \pm 0.08$ & $1.31 \pm 0.07$ & $1.33 \pm 0.08$ & $1.39 \pm 0.06$ \\
\hline \multicolumn{9}{|c|}{ Clay content $\left(\mathrm{g} \mathrm{kg}^{-1}\right)$} \\
\hline $0-10 \mathrm{~cm}$ & $192 \pm 41$ & $137 \pm 36$ & $429 \pm 40$ & $381 \pm 11$ & $287 \pm 49$ & $308 \pm 82$ & $105 \pm 13$ & $121 \pm 27$ \\
\hline $10-20 \mathrm{~cm}$ & $217 \pm 43$ & $148 \pm 34$ & $481 \pm 34$ & $451 \pm 16$ & $303 \pm 82$ & $267 \pm 64$ & $109 \pm 18$ & $142 \pm 23$ \\
\hline $20-60 \mathrm{~cm}$ & $248 \pm 33$ & $180 \pm 30$ & $494 \pm 25$ & $422 \pm 19$ & $321 \pm 68$ & $313 \pm 79$ & $131 \pm 12$ & $128 \pm 37$ \\
\hline $60-100 \mathrm{~cm}$ & $248 \pm 20$ & $188 \pm 23$ & $524 \pm 18$ & $459 \pm 30$ & $531 \pm 26$ & $556 \pm 48$ & $163 \pm 29$ & $179 \pm 26$ \\
\hline \multicolumn{9}{|c|}{ Silt content $\left(\mathrm{g} \mathrm{kg}^{-1}\right)$} \\
\hline $0-10 \mathrm{~cm}$ & $104 \pm 21$ & $51 \pm 36$ & $114 \pm 17$ & $109 \pm 26$ & $69 \pm 6$ & $51 \pm 6$ & $62 \pm 14$ & $84 \pm 20$ \\
\hline $10-20 \mathrm{~cm}$ & $89 \pm 17$ & $11 \pm 1$ & $104 \pm 22$ & $102 \pm 22$ & $74 \pm 12$ & $54 \pm 7$ & $78 \pm 13$ & $87 \pm 20$ \\
\hline $20-60 \mathrm{~cm}$ & $87 \pm 17$ & $20 \pm 13$ & $94 \pm 14$ & $105 \pm 28$ & $70 \pm 12$ & $54 \pm 9$ & $66 \pm 18$ & $79 \pm 17$ \\
\hline $60-100 \mathrm{~cm}$ & $92 \pm 19$ & $35 \pm 24$ & $122 \pm 28$ & $117 \pm 19$ & $53 \pm 4$ & $39 \pm 7$ & $93 \pm 23$ & $97 \pm 28$ \\
\hline \multicolumn{9}{|c|}{ Sand content $\left(\mathrm{g} \mathrm{kg}^{-1}\right)$} \\
\hline $0-10 \mathrm{~cm}$ & $705 \pm 42$ & $812 \pm 64$ & $457 \pm 29$ & $510 \pm 28$ & $645 \pm 44$ & $641 \pm 76$ & $833 \pm 21$ & $795 \pm 37$ \\
\hline $10-20 \mathrm{~cm}$ & $693 \pm 46$ & $842 \pm 35$ & $414 \pm 24$ & $447 \pm 22$ & $623 \pm 71$ & $679 \pm 64$ & $813 \pm 22$ & $771 \pm 40$ \\
\hline $20-60 \mathrm{~cm}$ & $665 \pm 30$ & $800 \pm 23$ & $412 \pm 21$ & $473 \pm 17$ & $609 \pm 58$ & $633 \pm 71$ & $803 \pm 8$ & $793 \pm 53$ \\
\hline $60-100 \mathrm{~cm}$ & $660 \pm 18$ & $777 \pm 21$ & $354 \pm 24$ & $424 \pm 49$ & $416 \pm 22$ & $405 \pm 42$ & $744 \pm 42$ & $724 \pm 40$ \\
\hline
\end{tabular}

a Soil survey according to the Brazilian classification (EMBRAPA, 2006) and its equivalence with FAO (2006) and USDA - Soil Taxonomy (Soil Survey Staff, 2010). 
and $0-100 \mathrm{~cm}$ depths by using Eq. (1). Positive values indicate a soil $\mathrm{C}$ stock accumulation and negative soil $\mathrm{C}$ stock depletion.

$\mathrm{C}_{\text {loss/accumulation }}=\frac{\mathrm{C}_{\text {current }}-\mathrm{C}_{\text {reference }}}{\mathrm{T}_{\text {LUC }}}$

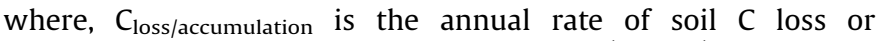
accumulation following the $\mathrm{LUC}\left(\mathrm{MgCha}^{-1}\right.$ year $\left.^{-1}\right), \mathrm{C}_{\text {current }}$ is the $\mathrm{C}$ stock under sugarcane plantation after $\operatorname{LUC}\left(\mathrm{MgCha}^{-1}\right)$, $\mathrm{C}_{\text {reference }}$ is the referential C stock before $\operatorname{LUC}\left(\mathrm{MgC} \mathrm{ha}^{-1}\right)$, and $\mathrm{T}_{\mathrm{LUC}}$ is the time since the initial LUC (years).

\subsection{Humification index assessed by Laser-Induced Fluorescence Spectroscopy}

The humification of SOM was assessed by using the LIFS technique (Milori et al., 2006). The portable LIFS system is a labmade equipment developed by Brazilian Agricultural Research Corporation - Embrapa Instrumentation. It comprises of a diode laser (Coherent - CUBE) emitting at $405 \mathrm{~nm}(50 \mathrm{~mW})$, an optical shutter, a bifurcated optical fiber bundle with seven optical fibers in a stainless steel ferrule: six illumination fibers around one read fiber (Ocean Optics), a high sensitivity mini-spectrometer (USB4000 - Ocean Optics), an adjustable optical filter, and a notebook. The resolution of the system was around $10 \mathrm{~nm}$ for all acquisition ranges $(475-800 \mathrm{~nm})$. In addition, software was developed to control the laser, the shutter, and spectrometer parameters such as integration time and number of averages for each measurement (Santos et al., 2015).

The measurements were done in triplicate for each soil sample and data were acquired according to the procedures described by Santos et al. (2015). The ratio between the area under fluorescence emission spectrum (range 475 and $800 \mathrm{~nm}$ ) and $\mathrm{C}$ concentration (in $\mathrm{g} \mathrm{kg}^{-1}$ ) for each sample was considered as an indicator of humification of SOM ( $\mathrm{H}_{\text {LIFS }}$ ), being expressed in arbitrary units (a. u.).

\subsection{Statistical analysis}

The statistical analysis of data was done according to a completely randomized sampling design, with the assumption that each paired-site had the same topographic and edaphoclimatic conditions. These areas are located side-by-side and therefore represent a chronosequence of the agricultural area. Assessment of the land use effects on total $C$ content, soil $C$ stocks and humification index was done by a two-sample $t$-test $(\mathrm{p}<0.05)$. The $t$-test was used to compare a long-established crop (reference land-use) versus a sugarcane plantation established after the LUC for soil sampled from different depths $(0-10,10-20,20-60$ and $60-$ $100 \mathrm{~cm}$ ) of the four paired areas. The two-sample $t$-test assumes that samples in each paired-site are obtained at random from normal population with equal variances. Therefore, the normality of data was confirmed by the Shapiro-Wilk test at 5\% of
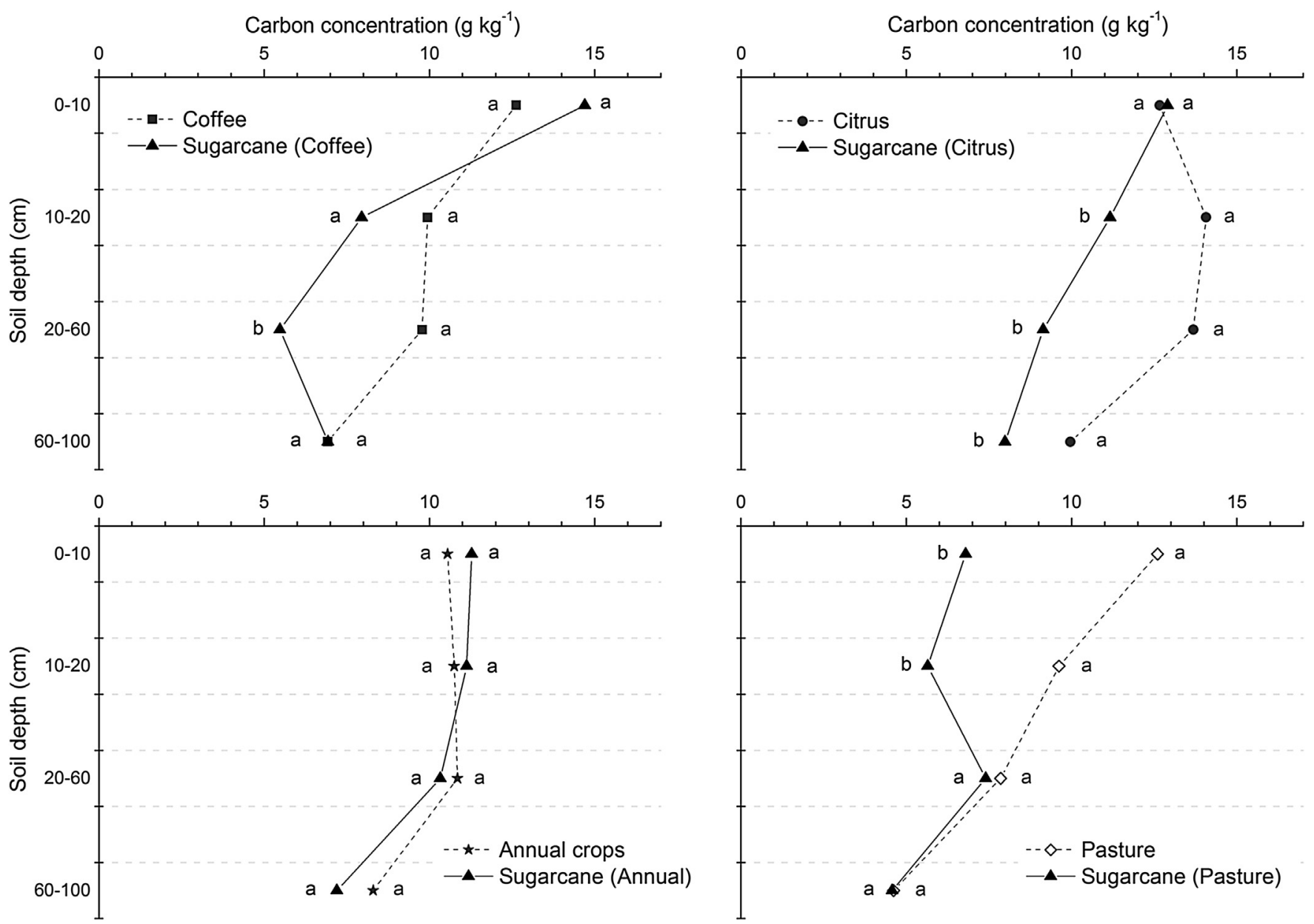

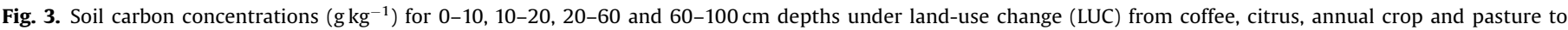

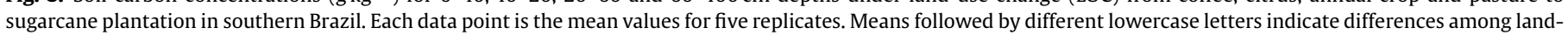
use systems (crops) for different soil depths of the paired areas (two-sample $t$-test at $\mathrm{p}<0.05$ ). 
significance. The data of humification index $\left(\mathrm{H}_{\text {LIFS }}\right)$ were logtransformed to achieve the normality. To test the hypothesis of equality between the variances for each paired area, the $F$ test was used at $5 \%$ probability level. The pooled variance was used to estimate the variance in case of non-rejection of the hypothesis of variance equality. Otherwise, the Satterthwaite approximation to the degrees of freedom was used in case of non-equality. All statistical analyses were performed using R software (R Development Core Team, 2015).

\section{Results}

\subsection{Total C content and soil C stocks}

The data on total $\mathrm{C}$ concentrations $\left(\mathrm{g} \mathrm{kg}^{-1}\right)$ for four soil depths $(0-10,10-20,20-60$ and $60-100 \mathrm{~cm})$ of the paired areas are shown in Fig. 3. The difference in the total $C$ concentration was significant $(\mathrm{p}<0.05)$ in the $20-60 \mathrm{~cm}$ soil layer upon conversion of coffee into sugarcane. Greater differences in total $C$ concentration in sub-soil are observed upon conversion of citrus into sugarcane in comparison with those for coffee to sugarcane, which does not have any soil cover in the inter-row zone (see Section 2.2). The LUC of citrus to sugarcane resulted in a significant change $(\mathrm{p}<0.05)$ in $\mathrm{C}$ concentration in 10-20, 20-60 and 60-100 cm layers. Regarding the transition of annual crop to sugarcane, there was no difference $(p>0.05)$ in soil $C$ concentration among land uses at any soil depths. Conversely, SOC concentration was significantly $(p<0.05)$ lower in the upper soil layers $(0-10$ and $10-20 \mathrm{~cm})$ under sugarcane than that of the adjacent pasture area. Considering the $\mathrm{C}$ concentration along the soil profile, decline of SOC was observed below $10 \mathrm{~cm}$ depth for almost all land uses of the paired areas (Fig. 3).

The overall effects of the LUC (conversions of coffee, citrus, annual crop and pasture into sugarcane) on soil $C$ stocks at different depths $(0-10,10-20,20-60$ and $60-100 \mathrm{~cm})$ and in the equivalent layers $(0-20$ and $0-100 \mathrm{~cm}$ ) are shown in Table 3 . Soil C stocks had a similar response relative to $C$ concentration at all depths. Effects of neither of the LUCs (e.g., coffee, citrus and annual crop) to sugarcane were statistically significant $(p>0.05)$ in the 0 $20 \mathrm{~cm}$ soil layer. Conversion of coffee and citrus resulted in loss of soil $\mathrm{C}$ at the rate of 0.12 and $0.90 \mathrm{MgC} \mathrm{ha}{ }^{-1}$ year $^{-1}$, respectively. On the contrary, a soil C accumulation rate of $0.24 \mathrm{MgC} \mathrm{ha}^{-1}$ year $^{-1}$ in the $0-20 \mathrm{~cm}$ layer was observed upon conversion of annual crops into sugarcane.
The conversion of pasture into sugarcane decreased soil $\mathrm{C}$ stock from 30.3 to $17.0 \mathrm{MgCha}^{-1}(43.9 \%)$ in the $0-20 \mathrm{~cm}$ layer $(\mathrm{p}<0.05)$, with a mean rate of soil C loss of $1.66 \mathrm{MgCha}^{-1}$ year $^{-1}$ (Table 3 ). Nevertheless, $C$ stocks in the sub-soil layers were not affected by LUC and management practices. There was no statistically significant difference $(p>0.05)$ in soil $C$ stocks among land uses under pasture and sugarcane established after pasture in the 0$100 \mathrm{~cm}$ layer. These trends indicate that sub-soil layers can retain more of the antecedent $C$ stocks following the land-use conversion. In this case, soil C was lost at the rate of $2.03 \mathrm{MgC} \mathrm{ha}^{-1} \mathrm{year}^{-1}$ in the $0-100 \mathrm{~cm}$ layer (Table 3 ).

Conversion of coffee to sugarcane depleted soil $\mathrm{C}$ stock from 124.5 to $99.8 \mathrm{MgCha}^{-1}(19.9 \%)$ in the $0-100 \mathrm{~cm}$ layer $(\mathrm{p}<0.05)$ at an average rate of $8.24 \mathrm{MgCha}^{-1}$ year $^{-1}$ over 3 years since the initial LUC. Similarly, conversion of citrus to sugarcane depleted soil C stock from 147.7 to $113.1 \mathrm{MgCha}^{-1}(23.4 \%)$ in the $0-100 \mathrm{~cm}$ layer $(\mathrm{p}<0.05)$ at an average rate of $8.66 \mathrm{MgCha}^{-1}$ year $^{-1}$ over 4 years. In contrast to the LUC of coffee and citrus, there was no significant difference in soil $C$ stocks in the $0-100 \mathrm{~cm}$ layer when sugarcane followed an annual crop $(\mathrm{p}>0.05)$. Conversion of annual crop to sugarcane depleted soil $\mathrm{C}$ stock at the rate of $0.98 \mathrm{MgC}$ $\mathrm{ha}^{-1}$ year $^{-1}$ in the $0-100 \mathrm{~cm}$ layer (Table 3 ).

\subsection{SOM humification level ( $\left.H_{\text {LIFS }}\right)$}

Similar to soil C stocks, assessment of the $\mathrm{H}_{\text {LIFS }}$ is also important to determining management-induced changes in SOM quality. The data presented in Fig. 4 compare the $\mathrm{H}_{\text {LIFS }}$ of SOM among land uses and soil depths. Each paired area being under the same soil type and climatic conditions, it was observed that most of the LUC to sugarcane under intensive tillage increased $\mathrm{H}_{\text {LIFS }}$ in the sub-soil, except in the pasture area $(\mathrm{p}<0.05)$. The $\mathrm{H}_{\text {LIFS }}$ for some depths was more than doubled in specific land uses under sugarcane in comparison with the previous land uses $(\mathrm{p}<0.05)$. This trend was especially true for conversions of coffee and citrus to sugarcane. Soil under pasture had lower $\mathrm{H}_{\text {LIFS }}$ in the $0-10$ and $10-20 \mathrm{~cm}$ layers compared with that under sugarcane established on pasture $(\mathrm{p}<0.05)$, and there was no difference in $\mathrm{H}_{\text {LIFS }}$ in sub-soil $(\mathrm{p}>0.05)$.

Total C content decreased with increase in soil depth (Fig. 3), a trend opposite to that of $\mathrm{H}_{\text {LIFS }}$ with soil depth (Fig. 4). In general, land-use systems had a smooth gradient of $\mathrm{H}_{\mathrm{LIFS}}$, which increased with soil depth. Most of the LUC (especially coffee, citrus and pasture) to sugarcane plantation under intensive tillage are depleting the soil C stock, which is in accord with the humification level of SOM observed herein.

Table 3

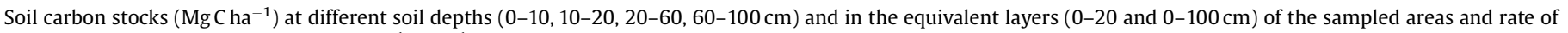

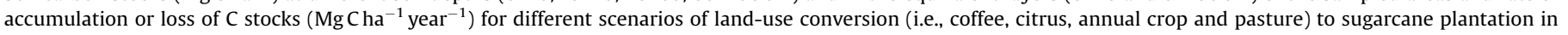

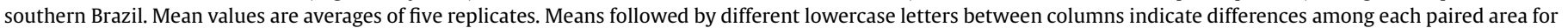
different soil layers (two-sample $t$-test at $\mathrm{p}<0.05$ ). Positive values indicate accretion and negative depletion of soil $C$ stocks.

\begin{tabular}{|c|c|c|c|c|c|c|c|c|}
\hline \multirow[t]{2}{*}{ Soil depth (cm) } & \multicolumn{2}{|c|}{ Paired Area 1} & \multicolumn{2}{|c|}{ Paired Area 2} & \multicolumn{2}{|l|}{ Paired Area 3} & \multicolumn{2}{|c|}{ Paired Area 4} \\
\hline & Coffee & Sugarcane & Citrus & Sugarcane & Annual crops & Sugarcane & Pasture & Sugarcane \\
\hline \multicolumn{9}{|c|}{ SOC stock ( $\left.\mathrm{MgCha} \mathrm{Ch}^{-1}\right)$} \\
\hline $0-10$ & $17.39 \mathrm{a}$ & $20.07 \mathrm{a}$ & $16.28 \mathrm{a}$ & $16.43 \mathrm{a}$ & $13.59 \mathrm{a}$ & $14.60 \mathrm{a}$ & $16.94 \mathrm{a}$ & $9.14 \mathrm{~b}$ \\
\hline $10-20$ & $15.57 \mathrm{a}$ & $12.54 \mathrm{a}$ & $18.26 \mathrm{a}$ & $14.51 \mathrm{~b}$ & $15.33 \mathrm{a}$ & $15.96 \mathrm{a}$ & $13.35 \mathrm{a}$ & $7.88 \mathrm{~b}$ \\
\hline $20-60$ & $55.38 \mathrm{a}$ & $30.92 \mathrm{~b}$ & $63.95 \mathrm{a}$ & $42.70 \mathrm{~b}$ & $65.19 \mathrm{a}$ & $62.16 \mathrm{a}$ & $45.52 \mathrm{a}$ & $42.86 \mathrm{a}$ \\
\hline $60-100$ & $36.16 \mathrm{a}$ & $36.23 \mathrm{a}$ & $49.20 \mathrm{a}$ & $39.42 \mathrm{~b}$ & $43.57 \mathrm{a}$ & $38.09 \mathrm{a}$ & $24.66 \mathrm{a}$ & $24.38 \mathrm{a}$ \\
\hline $0-20$ & $32.96 \mathrm{a}$ & $32.61 \mathrm{a}$ & $34.55 \mathrm{a}$ & $30.94 \mathrm{a}$ & $28.92 \mathrm{a}$ & $30.57 \mathrm{a}$ & $30.29 \mathrm{a}$ & $17.02 \mathrm{~b}$ \\
\hline $0-100$ & $124.50 \mathrm{a}$ & $99.77 \mathrm{~b}$ & $147.70 \mathrm{a}$ & $113.07 \mathrm{~b}$ & $137.68 \mathrm{a}$ & $130.81 \mathrm{a}$ & $100.47 \mathrm{a}$ & $84.25 \mathrm{a}$ \\
\hline \multicolumn{9}{|c|}{ Soil C loss/accumulation ( $\mathrm{MgCha}{ }^{-1}$ year $\left.^{-1}\right)$} \\
\hline $0-20$ & -0.12 & & -0.90 & & 0.24 & & -1.66 & \\
\hline $0-100$ & -8.24 & & -8.66 & & -0.98 & & 2.03 & \\
\hline
\end{tabular}



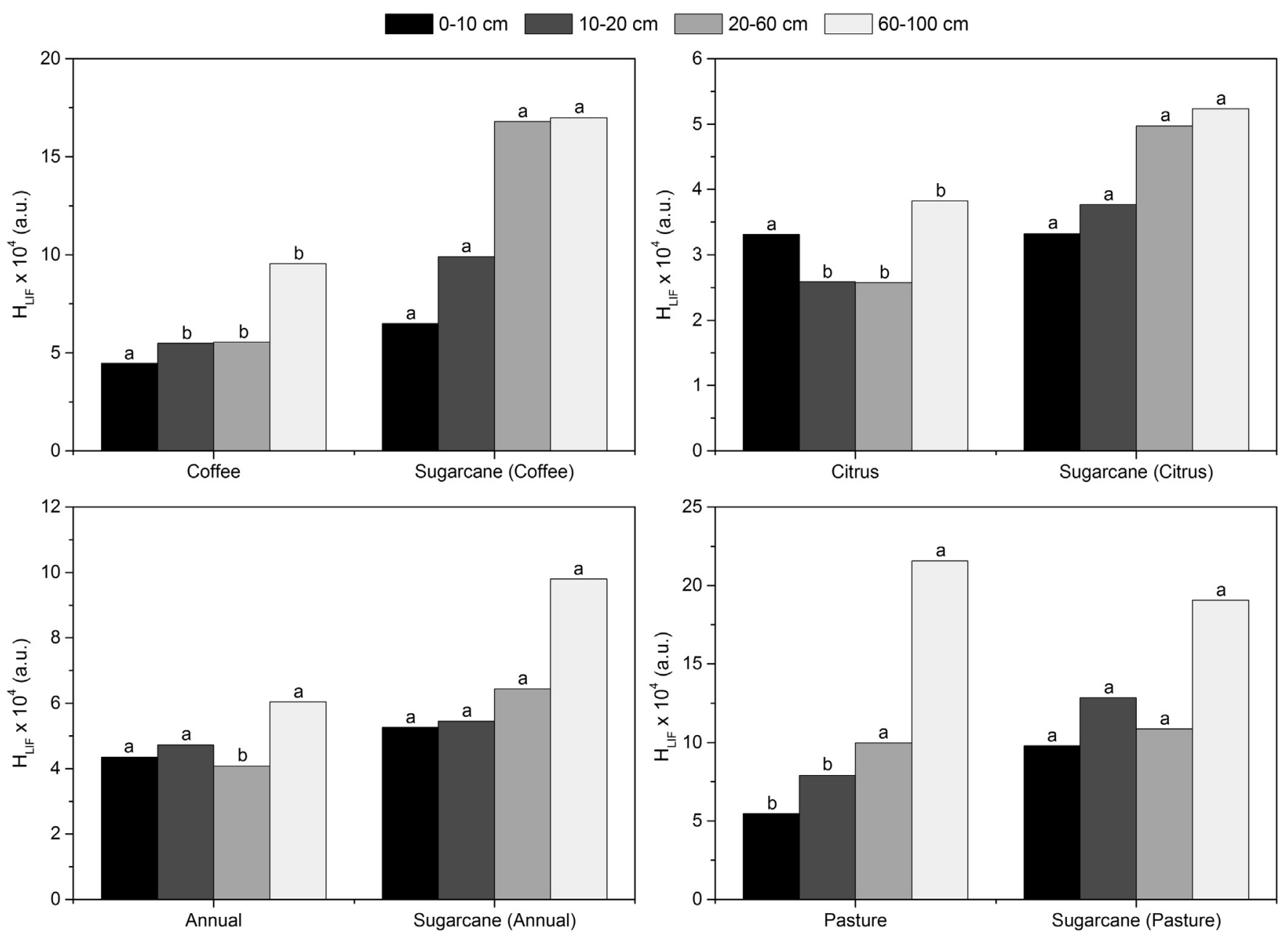

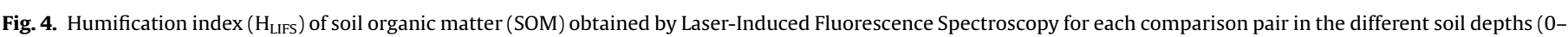

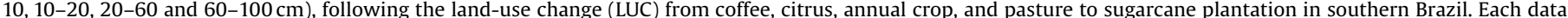

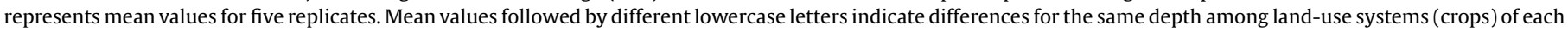
paired area (two-sample $t$-test at $\mathrm{p}<0.05$ ).

\section{Discussion}

\subsection{Changes in SOC storage induced by sugarcane expansion}

The absence of soil disturbance in the inter-rows over the last 8 and 15 years is likely the principal factor affecting the soil $\mathrm{C}$ debts upon conversion of coffee and citrus into sugarcane, respectively (Fig. 2; Table 3). Establishing sugarcane fields involves an intensive land preparation that causes substantial soil disturbance. Disruption of soil aggregates induced by conventional tillage (e.g., ploughing and/or harrowing) and the subsequent exposure of organic material to microbial processes exacerbates the depletion of SOC (Six et al., 1999). Experimental results from sugarcane fields indicate that soil $\mathrm{CO}_{2}$ emissions may be as much as $8.4 \mathrm{Mg} \mathrm{CO}_{2} \mathrm{ha}^{-1}$ for several weeks after tillage operations during the renewal of the sugarcane plantation (La Scala et al., 2006). This trend implies that most of the soil $C$ accumulated for several years can be lost when citrus and coffee are converted into sugarcane under conventional tillage. Such losses are especially high because sugarcane was recently converted from coffee and citrus. Therefore, it is important to be prudent in stating that soil $\mathrm{C}$ debts occur at high rates over short-term (e.g., 3 and 4 years) after conversions. Further research is needed to elucidate the impact of sugarcane expansion on soil C stocks during long periods upon conversion of perennial trees into sugarcane plantations.
Despite being in close proximity to sugarcane established on coffee, the paired area under coffee also has around 30\% more clay content than that of the adjacent sugarcane area (Table 2). There exists a strong interaction between clay fraction and SOC, so that clay particles tend to form aggregates that physically protect SOC from decomposition (Schimel et al., 1994). Thus, lower SOC stocks in sugarcane established on coffee may be attributed to the coarse texture of the soil, indicating that the impact of replanting operations on sandy soils would be more pronounced (Cerri et al., 2011).

Higher total C concentrations under coffee agrosystem may also be related to inter-row weed control by herbicides without any soil disturbance (see Section 2.2) as well as the high input of biomass-C in sub-soil through input of dead roots (Bicalho, 2011). Root distribution in a coffee plantation is relatively homogenous in the top $60 \mathrm{~cm}$ of soil (Hergoualc'h et al., 2012), in which are concentrated $75 \%$ of the total fine root biomass of the top $100 \mathrm{~cm}$ depth (Siles et al., 2010). In this study, coffee agrosystem provided a cumulative biomass- $\mathrm{C}$ input of $35.2 \mathrm{Mg} \mathrm{C}^{-1}$ (aboveand belowground) over 8 years and without soil disturbance (Table 1; Fig. 2). Therefore, root distribution and activity may determine the enrichment of soil C stock (Hergoulalc'h et al., 2012).

The maintenance of the soil cover with grass (Brachiaria spp.) in the inter-rows and without any soil disturbance is also an important factor for increasing SOC storage under citrus compared 
with that under sugarcane established after citrus. Soil under citrus (with grass in the inter-row) had large amounts of biomass-C input $\left(49.5+34.4 \mathrm{MgCha}^{-1}\right.$ over 15 years) compared with that of the adjacent sugarcane area $\left(29.6 \mathrm{MgCha}^{-1}\right.$ over 4 years) (Table 1 ). After evaluating the effect of a 6-year period of permanent cover species between the citrus trees, Balota and Auler (2011) reported that strip tillage with Brachiaria spp. increased SOC by up to $70 \%$ in the inter-row zone compared to the antecedent value. Reduction in the intensity of soil disturbance associated with cover species between the trees in perennial crop systems can change soil aggregation, and residue amounts and rooting depth, thereby affecting soil microbial diversity and C concentration (Dick, 1992; Balota and Auler, 2011). Similarly, the aggregate stability is improved within the rhizosphere, which produces high levels of macroaggregation (Bronick and Lal, 2005). Perennial tree crops (e.g., citrus and coffee) have a deeper root biomass compared to that under sugarcane, which strongly impacts soil aggregation and SOC levels (Bicalho, 2011). This is a high researchable priority.

The data presented show no differences in any soil layer (0-20 and $0-100 \mathrm{~cm}$ ) when annual crops were converted into sugarcane. In contrast, Mello et al. (2014) reported that conversion of annual cropland to sugarcane increased soil C stocks $(0-100 \mathrm{~cm})$ from 126.7 to $148.2 \mathrm{MgCha}^{-1}$ (17\%) over 20-year. However, such increases have not been a consensus among 13 comparison pairs, since the soil C stocks increased in seven sites following conversion to sugarcane, whereas six sites decreased. The apparent contradiction between the results reported herein and those by Mello and colleagues may be attributable to specific soil type, climate conditions and agricultural practices. In this study, the annual crop area was under intensive soil tillage in the last years of cultivation (e.g., 2-3 times per year), whereas soils under sugarcane were tilled twice over 7 years after replacing an annual crop (Fig. 2). Furthermore, the harvest residues were not returned to the soil in the sugarcane converted from annual crop during the last 4 years, thereby resulting in lower amounts of biomass-C input $(29.8 \mathrm{Mg}$ $\mathrm{Cha}^{-1}$ ) compared to those under annual crop $\left(40.5 \mathrm{MgCha}^{-1}\right)$ (Table 1).

Among several factors influencing soil $C$ stock with LUC, the effects of management practices (e.g., tillage operations and crop residue management) are among principal causes of changes in soil C stocks at several sites (Murty et al., 2002; Anderson-Teixeira et al., 2009). Decline in SOC concentration in the surface layers when sugarcane followed pasture is attributed to a high rate of SOM decomposition, which is accentuated by soil disturbance during the planting operation (La Scala et al., 2006; Silva-Olaya et al., 2013; De Figueiredo et al., 2015). The intensity of tillage operations enhances the interaction between SOM and oxygen diffusion, as well as induces the aggregates breakdown, thereby increasing the exposure of the protected SOM (Silveira et al., 2000; Murty et al., 2002). Conversely, tillage is absent in pastures for long periods (Mello et al., 2014). Furthermore, soils in those paired areas (pasture vs. sugarcane established on pasture) have a sandy texture (Table 2), which is more prone to losing $C$ that is not protected within aggregates (Dieckow et al., 2009). Thus, soil C depletion would be accentuated by tillage operations following the conversion to sugarcane plantation.

In accord with previous studies (Rossi et al., 2013; Mello et al., 2014; Franco et al., 2015), the lack of soil disturbance in pasture over the last 10 years and the adoption of burned harvest system during 6 years in sugarcane established on pasture may explain higher $\mathrm{C}$ stocks under pasture than that under adjacent sugarcane area (Fig. 2). However, significant differences were observed only in the upper $20 \mathrm{~cm}$ of soil (Table 3). These data are in accord with those of Franco et al. (2015) who reported average losses in soil C stock of $29.1 \mathrm{MgC} \mathrm{ha}^{-1}$ (40\%) in the $0-30 \mathrm{~cm}$ layer over 20 years upon conversion from pasture to sugarcane in a soil of the Brazilian
Cerrado region. This period included more than 10 years under burned harvest management, which severely depletes soil C stocks (Robertson and Thorburn, 2007; Galdos et al., 2009).

In some cases, soils under sugarcane could have similar or larger $C$ stocks than those under pasture, depending on the status of pasture degradation, the time since land-use conversion and the adoption of best management practices in sugarcane fields (e.g., green cane management, reduced tillage and no-till). Considering those sugarcane areas which have been harvested without burning since their establishment, Oliveira et al. (2016) reported that conversion of pasture to sugarcane increased soil C stock from 95.5 to $111.6 \mathrm{Mg} \mathrm{ha}^{-1}\left(1.97 \mathrm{Mg} \mathrm{ha}^{-1}\right.$ year $\left.^{-1}\right)$ for the $0-100 \mathrm{~cm}$ layer. Oliveira and colleagues also concluded that SOM assessments restricted to the surface soil layers can lead to a bias in studies regarding LUC, since there was no difference in the upper layers of soil.

Osher et al. (2003) reported that some of the $C$ depleted in the topsoil under a sugarcane plantation was translocated into the subsoil, and concluded that the loss of $C$ upon land-use conversion can be overestimated if gains in the sub-soil are not considered. Similar discrepancy was observed in the present study for conversion of pasture to sugarcane, in which a soil $\mathrm{C}$ depletion was significant $(\mathrm{p}<0.05)$ only for the $0-20 \mathrm{~cm}$ layer. There were no differences in soil C stocks for the $0-100 \mathrm{~cm}$ layer (Table 3 ), indicating the need for considering the changes in soil $\mathrm{C}$ stocks in sub-soil layers to credibly assess the impacts of LUC on $C$ budgets in agroecosystems (Batlle-Bayer et al., 2010; Oliveira et al., 2016).

While inappropriate management practices may deplete soil $\mathrm{C}$ stocks, adoption of best management practices can reduce soil $\mathrm{C}$ losses upon conversion of pasture into sugarcane (Batlle-Bayer et al., 2010). Higher C stocks are likely to be expected in this study whether sugarcane areas were converted from pasture under a green cane management. Canellas et al. (2007) observed that the straw burning in sugarcane fields over 55 years decreased soil C stock by $40 \%$ in the topsoil and $35 \%$ in sub-soil compared with a green cane management (i.e., non-burning). Consequently, the longer the period of time with stalk burning management, the greater are the losses of soil C stocks (Rossi et al., 2013).

There exists a vast potential for soil $C$ accretion in sugarcane fields through adoption of green cane management (Cerri et al., 2011). La Scala et al. (2012) reported that green harvest system (non-burning practice) can sequester as much as $1.87 \pm 0.20 \mathrm{Mg}$ $\mathrm{Cha}^{-1}$ year $^{-1}$ in topsoil compared with that under the burning practice prior to harvest. However, the simple conversion of sugarcane fields from burned to green harvest system does not guarantee significant increases in soil $\mathrm{C}$ stocks over time. Tillage operations in sugarcane accentuate soil $\mathrm{CO}_{2}-\mathrm{C}$ emissions during field preparation (La Scala et al., 2006; Silva-Olaya et al., 2013), which is conducted typically every five to six years after planting. In a 7-year study, Segnini et al. (2013) isolated the impacts of the maintenance of straw on the soil surface and tillage operations during sugarcane renovation. The authors observed that adoption of green cane and conventional tillage accumulated $0.67 \mathrm{MgC}$ $\mathrm{ha}^{-1}$ year $^{-1}$ compared with $1.63 \mathrm{Mg} \mathrm{Cha}^{-1}$ year $^{-1}$ of sequestration under green cane and no-till.

The sugarcane straw (i.e., $10-20 \mathrm{Mg} \mathrm{ha}^{-1}$ of dry matter) left on the ground under no-till can create a favorable long-term soil $\mathrm{C}$ budget in sugarcane fields (Anderson-Teixeira et al., 2009), so that the total eradication of straw burning plus the introduction of sugarcane into pastures with low $\mathrm{C}$ contents are key opportunities to further enhance the $C$ savings of Brazilian sugarcane ethanol (Oliveira et al., 2016). The data presented herein suggest that converting coffee and citrus into sugarcane leads to large soil C losses that may counteract the benefits of fossil fuel displacement. Considering an ethanol $\mathrm{C}$ offset of $9.8 \mathrm{MgCO}_{2} \mathrm{ha}^{-1}$ year $^{-1}$ by substituting fossil fuels (Fargione et al., 2008), the magnitude of 
soil $\mathrm{C}$ debt would take around 9 and 13 years to recover upon conversion of coffee and citrus into sugarcane, respectively. Therefore, it is imperative to avoid converting citrus and coffee into sugarcane as an important strategy to ensure the environmental benefits of sugarcane ethanol in Brazil.

\subsection{Sugarcane expansion and implications for SOM quality}

The data of humification index $\left(\mathrm{H}_{\mathrm{LIFS}}\right)$ are coherent with those of $\mathrm{C}$ stocks, suggesting that lower $\mathrm{H}_{\mathrm{LIFS}}$ is related to higher $\mathrm{C}$ concentration and vice versa. $\mathrm{C}$ concentrations in sub-soil are lower, more stabilized and bound with clay particles forming a humus-clay complex in relation to those in the topsoil (Martins et al., 2011). In this context, $\mathrm{H}_{\text {LIFS }}$ increased from the surface to the deepest layers for most of the land-use types. Such a trend is likely to be related to the presence of labile $C$ in the $0-10$ and $10-20 \mathrm{~cm}$ soil layers. The constant deposition of fresh organic matter from sugarcane straw (e.g., green harvest system) and the inputs of senesced leaves and dead roots in pasture area overwhelm the capacity of microorganisms to decompose them (Segnini et al., 2013), thereby resulting in a less aromatic or less humified humic substances (Milori et al., 2006). Fontaine et al. (2007) reported that the stability of organic $C$ is maintained with the absence of fresh organic $C$ in sub-soil, which is an essential source of energy for soil microbes. In these circumstances, there is further decomposition of humic substances by microorganisms (González-Pérez et al., 2007), which increases the degree of aromaticity and humification.

When sugarcane replaced coffee and citrus (Fig. 4), there was an incidence of a more condensed/aromatic character for organic matter in sub-soil (e.g., humification process), which could be associated with higher occurrence of more physically protected structures in deeper layers (Martins et al., 2015). In addition, higher $\mathrm{H}_{\text {LIFS }}$ in sub-soil is likely to be related to the illuviation of humic substances from surface into the sub-soil (Krull et al., 2002), indicating a more humified SOM and a less labile structure with soil depth. Higher clay content in soils under coffee also explains the lesser humification of SOM than that of the adjacent sugarcane area (Dieckow et al., 2009; Martins et al., 2011), which has around $30 \%$ less clay content (Table 2).

Lower $\mathrm{H}_{\text {LIFS }}$ in sub-soil under coffee and citrus compared with soil under sugarcane could be attributable to vigorous root system of perennial tree crops. Similar to the deep-rooted grasses, perennial tree crops (e.g., coffee and citrus) also have a deep root system, and transfer $C$ into the sub-soil which is less prone to oxidation and loss (Fisher et al., 1994). Roots are thus major contributors to stable SOM build-up, especially in deep soil layers (Rasse et al., 2005). Furthermore, the maintenance of the soil cover with grass (Brachiaria spp.) in the inter-rows may have led to lower $\mathrm{H}_{\text {LIFS }}$ (i.e., 10-20 cm; Fig. 4) in soils under citrus compared with those under sugarcane (Martins et al., 2015). Although sugarcane straw is being left on the soil surface, it is apparent that the current management of sugarcane established on coffee and citrus is not incorporating $C$ and fresh organic matter into the soil solum.

Tillage systems also influence SOM dynamics and its quality (Bayer et al., 2002). Enhanced soil aggregation and the incorporation of labile organic compounds in aggregates are positively correlated with those in undisturbed soils plus the maintenance of crop residues on the soil surface (Tivet et al., 2013). Although the retention of crop residues seems to be an efficient pathway for restoring soil C stock, Segnini et al. (2013) reported that the incorporation of sugarcane straw under conventional tillage did not improve soil $\mathrm{C}$ accumulation and its quality. The organic matter in soils managed by conventional tillage is more recalcitrant than that in soils managed with no-till, and therefore have higher $\mathrm{H}_{\text {LIFS }}$ in its SOM (Milori et al., 2006; González-Pérez et al., 2007; Dieckow et al., 2009).
Converting pastures into sugarcane would promote high oxidation in the labile organic compounds due to soil disturbance (e.g., ploughing and/or harrowing), and therefore there is a greater proportion of more recalcitrant structures in total SOM. In the present study, pasture had no soil disturbance over the last 10 years (Fig. 2), and thus lower $\mathrm{H}_{\mathrm{LIFS}}$ in the surface soil is expected compared with that of the adjacent sugarcane area (Fig. 4). This trend also indicates that some other protection mechanisms (e.g., physical protection in aggregates) are not effective in protecting the most labile fractions of the organic matter in soils under sugarcane (Milori et al., 2006). High structural stability under pasture improves the labile moieties of SOM through physical protection mechanism, which leads to lower humification of SOM (Franco et al., 2015). Results presented herein are in agreement with those of Rossi et al. (2013) and Franco et al. (2015), indicating a more intensive decomposition of SOM through tillage operations and a possible accumulation of more recalcitrant $C$ related to sugarcane expansion.

While the most recalcitrant structures of SOM tend to remain under higher tillage intensities and lower residues inputs (Segnini et al., 2013), a higher $C$ input from crop residues increases labile $C$ in the SOM, decreasing its humification degree (Raphael et al., 2016). However, it is important to be cautious in stating that higher $\mathrm{C}$ inputs lead to decreased $\mathrm{H}_{\text {LIFs. Conventional tillage operations in }}$ sugarcane invert the soil and bury crop residues, which increase the interaction of fresh residues with high oxygenation and stimulate the mineralization of labile $C$ fraction present in SOM, and therefore it attains more advanced oxidation stages (Bayer et al., 2002; Fontaine et al., 2007). On the other hand, the microbial metabolization capacity can be exceeded with high additions of crop residues under no-till, which would be partially decomposed, thereby resulting in a less humified organic matter (Bayer et al., 2002). It is evident therefore that the short-term maintenance of sugarcane straw on the soil surface was not long enough to improve soil $\mathrm{C}$ accumulation and reverse the increased oxidation level of SOM induced by conventional tillage (e.g., planting operations) upon conversion of pasture into sugarcane.

\section{Conclusions}

Land use change leads to large variations in soil C stocks associated with sugarcane expansion in southern Brazil. Conversions from coffee and citrus to sugarcane plantation significantly depleted soil C stock for the $0-100 \mathrm{~cm}$ layer in short-term. The conversion of pasture to sugarcane is comparatively less adverse in terms of soil $\mathrm{C}$ losses, depleting $\mathrm{C}$ stocks only for the 0 $20 \mathrm{~cm}$ layer. This evidence highlights the need of assessing the soil C stock for the entire profile to credibly quantify the impacts of LUC on soil $\mathrm{C}$ budget in agroecosystems. There was no difference in soil $C$ stock among land uses at any soil depths upon conversion of annual crop to sugarcane, which does not support the hypothesis that such transition increases soil C stock and therefore its quality.

Overall, humification stages of SOM had a smooth gradient from the top to the deepest layers for most of the land-use systems, increasing with soil depth. The magnitude of $\mathrm{H}_{\mathrm{LIFS}}$ indicated that the sugarcane expansion increased oxidation stages of SOM in subsoil for most of the evaluated pairs (e.g., coffee and citrus), except in pasture area, which had lower humification level in the surface layers of soil compared to that under sugarcane established on pasture. Therefore, it is prudent to avoid converting citrus and coffee into sugarcane plantation. Additional research is needed to validate these findings for considering the introduction of sugarcane into pastures with low $C$ contents as an opportunity to further enhance the environmental benefits of sugarcane-based ethanol. 


\section{Acknowledgements}

The authors would like to thank the Brazilian Agricultural Research Corporation - Embrapa Satellite Monitoring (CarbCana project; SEG: 02.12.08.002.00.00), the National Council for Scientific and Technological Development-CNPq (contract grants number 142232/2012-2), the Brazilian Federal Agency for Support and Evaluation of Graduate Education-PDSE/CAPES (contract grants number 7765/13-4), and Sao Paulo Research FoundationFAPESP (contract grants number 2008/58187-0) for the grants awarded for the development of this study. We thank Dr. Alan Rodrigo Panosso for his comments on the data analysis, as well as two anonymous reviewers for their constructive suggestions.

\section{References}

Adami, M., Theodor Rudorff, B.F., Freitas, R.M., Aguiar, D.A., Sugawara, L.M., 2012. Remote sensing time series to evaluate direct land use change of recent expanded sugarcane crop in Brazil. Sustainability 4, 574-585.

Anderson-Teixeira, K.J., Davis, S.C., Masters, M.D., Delucia, E.H., 2009. Changes in soil organic carbon under biofuel crops. Glob. Change Biol. Bioenergy 1, 75-96.

Börjesson, P., 2009. Good or bad bioethanol from a greenhouse gas perspective -what determines this? Appl. Energy 86, 589-594.

Balota, E.L., Auler, P.A.M., 2011. Soil microbial biomass under different management and tillage systems of permanent intercropped cover species in an orange orchard. Rev. Bras. Cienc. Solo 35, 1873-1883.

Batlle-Bayer, L., Batjes, N.H., Bindraban, P.S., 2010. Changes in organic carbon stocks upon land use conversion in the Brazilian Cerrado: a review. Agric. Ecosyst. Environ. 137, 47-58.

Bayer, C., Mielniczuk, J., Martin-Neto, L., Ernani, P.R., 2002. Stocks and humification degree of organic matter fractions as affected by no-tillage on a subtropical soil. Plant Soil 238, 133-140.

Bicalho, I.M., 2011. Alteração na agregação e carbono orgânico total em solo cultivado com café sob diferentes sistemas de manejo. Encicl. Biosf. 7, 1-14.

Blake, G.R., Hartge, K.H., 1986. Bulk density, In: Klute, A. (Ed.), Methods of Soil Analysis. Part 1. Physical and Mineralogical Methods. 2nd ed. American Society of Agronomy Madison, WI, USA, pp. 363-375.

Bordonal, R.O., Lal, R., Alves Aguiar, D., De Figueiredo, E.B., Ito Perillo, L., Adami, M., Theodor Rudorff, B.F. La Scala, N., 2015. Greenhouse gas balance from cultivation and direct land use change of recently established sugarcane (Saccharum officinarum) plantation in south-central Brazil. Renew. Sustainable Energy Rev. 52, 547-556.

Bronick, C.J., Lal, R., 2005. Soil structure and management: a review. Geoderma 124 $3-22$.

Campanha, M.M., Santos, R.H.S., Freitas, G.D., Martinez, H.E.P., Jaramillo-Botero, C., Garcia, S.L., 2007. Análise comparativa das características da serrapilheira e do solo em cafezais (Coffea arabica L.) cultivados em sistema agroflorestal e em monocultura na zona da mata MG. Rev. Árvore 31, 805-812.

Canellas, L.P., Baldotto, M.A., Busato, J.G., Marciano, C.R., Menezes, S.C., da Silva, N. M., Rumjanek, V.M., Velloso, A.C.X., Simões, M.L., Martin-Neto, L., 2007. Estoque e qualidade da matéria orgânica de um solo cultivado com cana-de-açúcar por longo tempo. Rev. Bras. Cienc. Solo 31, 331-340.

Carvalho, J.L.N., Cerri, C.E.P., Feigl, B.J., Píccolo, M.C., Godinho, V.P., Cerri, C.C., 2009. Carbon sequestration in agricultural soils in the Cerrado region of the Brazilian Amazon. Soil Till. Res. 103, 342-349.

Carvalho, J.L.N., Hudiburg, T.W., Franco, H.C.J., Delucia, E.H., 2016. Contribution of above- and belowground bioenergy crop residues to soil carbon. Glob. Change Biol. Bioenergy doi:http://dx.doi.org/10.1111/gcbb.12411 (in press).

Cerri, C.C., Galdos, M.V., Maia, S.M.F., Bernoux, M., Feigl, B.J., Powlson, D., Cerri, C.E.P., 2011. Effect of sugarcane harvesting systems on soil carbon stocks in Brazil: an examination of existing data. Eur. J. Soil Sci. 62, 23-28.

Cherubin, M.R., Franco, A.L.C., Cerri, C.E.P., Oliveira d, D.M.S., Davies, C.A., Cerri, C.C., 2015. Sugarcane expansion in Brazilian tropical soils-effects of land use change on soil chemical attributes. Agric. Ecosyst. Environ. 211, 173-184.

De Figueiredo, E.B., Panosso, A.R., Reicosky, D.C., La Scala, N., 2015. Short-term CO2-C emissions from soil prior to sugarcane (Saccharum spp.) replanting in southern Brazil. Glob. Change Biol. Bioenergy 7, 316-327.

Defrenet, E., Roupsard, O., Van den Meersche, K., Charbonnier, F., Pérez-Molina, J.P., Khac, E., Prieto, I., Stokes, A., Roumet, C., Rapidel, B., Virginio Filho, E.M., Vargas, V.J., Robelo, D., Barquero, A., Jourdan, C., 2016. Root biomass, turnover and net primary productivity of a coffee agroforestry system in Costa Rica: effects of soil depth shade trees, distance to row and coffee age. Ann. Bot. 118, 833-851.

Dick, R.P., 1992. Biotic diversity in agroecosystems A review: long-term effects of agricultural systems on soil biochemical and microbial parameters. Agric. Ecosyst. Environ. 40, 25-36.

Dieckow, J., Bayer, C., Conceição, P.C., Zanatta, J.A., Martin-Neto, L., Milori, D.B.M., Salton, J.C., Macedo, M.M., Mielniczuk, J., Hernani, L.C., 2009. Land use, tillage, texture and organic matter stock and composition in tropical and subtropical Brazilian soils. Eur. J. Soil Sci. 60, 240-249.

Don, A., Osborne, B., Hastings, A., Skiba, U., Carter, M.S., Drewer, J., Flessa, H., Freibauer, A., Hyvönen, N., Jones, M.B., Lanigan, G.J., Mander, Ü., Monti, A.,
Djomo, S.N., Valentine, J., Walter, K., Zegada-Lizarazu, W., Zenone, T., 2012. Land-use change to bioenergy production in Europe: implications for the greenhouse gas balance and soil carbon. Glob. Change Biol. Bioenergy 4, $372-$ 391.

dos Santos, R.S.M., de Oliveira, I.P., de Morais, R.F., Urquiaga, S.C., Boddey, R.M., Alves, B.J.R., 2007. Componentes da parte aérea e raízes de pastagens de Brachiaria spp. em diferentes idades após a reforma, como indicadores de produtividade em ambiente de Cerrado. Pesq. Agropec. Trop. 37, 119-124.

EMBRAPA, 1997. Manual de métodos de análise de solo (In Portuguese), Centro Nacional De Pesquisa De Solos. 2nd ed. Empresa Brasileira de Pesquisa Agropecuária (EMBRAPA-CNPS), Rio de Janeiro, Brazil.

EMBRAPA, 2006. Sistema brasileiro de classificação de solos (In portuguese), Centro Nacional De Pesquisa De Solos. 2nd ed. Empresa Brasileira de Pesquisa Agropecuária (EMBRAPA-CNPS), Rio de Janeiro, Brazil.

Ellert, B.H., Bettany, J.R., 1995. Calculation of organic matter and nutrients stored in soils under contrasting management regimes. Can. J. Soil Sci. 75, 529-538.

FAO, 2006. Guidelines for Soil Description, 4th ed. Food and Agriculture Organization of the United Nations, Rome.

Fargione, J., Hill, J., Tilman, D., Polasky, S., Hawthorne, P., 2008. Land clearing and the biofuel carbon debt. Science 319, 1235-1238

Fisher, M.J., Rao, I.M., Ayarza, M.A., Lascano, C.E., Sanz, J.I., Thomas, R.J., Vera, R.R., 1994. Carbon storage by introduced deep-rooted grasses in the South American savannas. Nature 371, 236-238.

Fontaine, S., Barot, S., Barre, P., Bdioui, N., Mary, B., Rumpel, C., 2007. Stability of organic carbon in deep soil layers controlled by fresh carbon supply. Nature 450 277-280.

Franco, A.L., Cherubin, M.R., Pavinato, P.S., Cerri, C.E., Six, J., Davies, C.A., Cerri, C.C., 2015. Soil carbon: nitrogen and phosphorus changes under sugarcane expansion in Brazil. Sci. Total Environ. 515-516, 30-38.

Galdos, M.V., Cerri, C.C., Cerri, C.E.P., 2009. Soil carbon stocks under burned and unburned sugarcane in Brazil. Geoderma 153, 347-352.

Goldemberg, J., Mello, F.F.C., Cerri, C.E.P., Davies, C.A., Cerri, C.C., 2014. Meeting the global demand for biofuels in 2021 through sustainable land use change policy. Energy Policy 69, 14-18.

Goldemberg, J., 2007. Ethanol for a sustainable energy future. Science 315, 808-810.

González-Pérez, M., Milori, D.M.B.P., Colnago, L.A., Martin-Neto, L., Melo, W.J., 2007. A laser-induced fluorescence spectroscopic study of organic matter in a Brazilian Oxisol under different tillage systems. Geoderma 138, 20-24.

Hergoualc'h, K., Blanchart, E., Skiba, U., Hénault, C., Harmand, J.-M., 2012. Changes in carbon stock and greenhouse gas balance in a coffee (Coffea arabica) monoculture versus an agroforestry system with Inga densiflora, in Costa Rica. Agric. Ecosyst. Environ. 148, 102-110.

Krishna, K.R., 2013. Chapter 32, soil organic matter and nutrient dynamics. Agroecosystems: Soils, Climate, Crops, Nutrient Dynamics and Productivity. Apple Academic Press, pp. 410-427.

Krull, E.S., Bestland, E.A., Gates, W.P., 2002. Soil organic matter decomposition and turnover in a tropical Ultisol; evidence from delta (super 13) C, delta (super 15) $\mathrm{N}$ and geochemistry. Radiocarbon 44, 93-112.

La Scala Jr., N., Bolonhezi, D., Pereira, G.T., 2006. Short-term soil CO2 emission afte conventional and reduced tillage of a no-till sugar cane area in southern Brazil. Soil Till. Res. 91, 244-248.

La Scala Jr, N., De Figueiredo, E.B., Panosso, A.R., 2012. A review on soil carbon accumulation due to the management change of major Brazilian agricultural activities. Braz. J. Biol. 72, 775-785.

Lal, R., 2004a. Soil carbon sequestration impacts on global climate change and food security. Science 304, 1623-1627.

Lal, R., 2004b. Soil carbon sequestration to mitigate climate change. Geoderma 123 , $1-22$.

Lapola, D.M., Schaldach, R., Alcamo, J., Bondeau, A., Koch, J., Koelking, C., Priess, J.A., 2010. Indirect land-use changes can overcome carbon savings from biofuels in Brazil. Proc. Natl. Acad. Sci. U. S. A. 107, 3388-3393.

Le Quéré, C., Moriarty, R., Andrew, R.M., Canadell, J.G., Sitch, S., Korsbakken, J.I., Friedlingstein, P., Peters, G.P., Andres, R.J., Boden, T.A., et al., 2015. Global carbon budget 2015. Earth Syst. Sci. Data 7, 349-396.

MCTI, 2010. Segunda Comunicação Nacional Do Brasil à Convenção-Quadro Das Nações Unidas Sobre Mudança Do Clima. Ministério da Ciência, Tecnologia e Inovação, Brasília/DF, pp. 520 ([cited 2015 August 12]. Available at: http://www. mct.gov.br/index.php/content/view/326988.html).

MCTI, 2014. Estimativas Anuais De Emissões De Gases De Efeito Estufa No Brasil, 2nd ed. Ministério da Ciência, Tecnologia e Inovação, Brasília/DF, pp. 161 ([cited 2016 June 25]. Available at: http://www.mct.gov.br/upd_blob/0235/235580.pdf).

Martins, T., Saab, S.C., Milori, D.M.B.P., Brinatti, A.M., Rosa, J.A., Cassaro, F.A.M., Pires, L.F., 2011. Soil organic matter humification under different tillage managements evaluated by Laser Induced Fluorescence (LIF) and C/N ratio. Soil Till. Res. 111, 231-235.

Martins, B.H., Araujo-Junior, C.F., Miyazawa, M., Vieira, K.M., Milori, D.M.B.P., 2015 Soil organic matter quality and weed diversity in coffee plantation area submitted to weed control and cover crops management. Soil Till. Res. 153, 169174.

Mello, F.F.C., Cerri, C.E.P., Davies, C.A., Holbrook, N.M., Paustian, K., Maia, S.M.F., Galdos, M.V., Bernoux, M., Cerri, C.C., 2014. Payback time for soil carbon and sugar-cane ethanol. Nat. Clim. Change 4, 605-609.

Milori, D.M.B.P., Galeti, H.V.A., Martin-Neto, L., Dieckow, J., González-Pérez, M., Bayer, C., Salton, J., 2006. Organic matter study of whole soil samples using laser-Induced fluorescence spectroscopy. Soil Sci. Soc. Am. J. 70, 57-63. 
Murty, D., Kirschbaum, M.U.F., McMurtrie, R.E., McGilvray, H., 2002. Does conversion of forest to agricultural land change soil carbon and nitrogen?: a review of the literature. Glob. Change Biol. 8, 105-123.

Nelson, D.W., Sommers, L.E., 1982. Total carbon, organic, and organic matter. In: Page, A.L., Miller, R.H., Keeney, D.R. (Eds.), Methods of Soil Analysis. Part 2. American Society of Agronomy Madison, WI, USA, pp. 539-579.

Nepstad, D., McGrath, D., Stickler, C., Alencar, A., Azevedo, A., 2014. Slowing Amazon deforestation through public policy and interventions in beef and soy supply chains. Science 344, 1118-1123.

Oliveira Filho, A.T., Ratter, J.A., 2000. Padrões florísticos das matas ciliares da região do cerrado e a evolução das paisagens do Brasil Central durante o Quaternário Tardio. In: Rodrigues, R.R., Leitão Filho, H.F. (Eds.), Matas Ciliares: Conservação E Recuperação. EDUSP: Universidade de São Paulo, São Paulo, pp. 73-89.

Oliveira, D.M.S., Paustian, K., Davies, C.A., Cherubin, M.R., Franco, A.L.C., Cerri, C.C. Cerri, C.E.P., 2016. Soil carbon changes in areas undergoing expansion of sugarcane into pastures in south-central Brazil. Agric. Ecosyst. Environ. 228, 38 48.

Osher, L., Matson, P., Amundson, R., 2003. Effect of land use change on soil carbon in Hawaii. Biogeochemistry 65, 213-232.

R Development Core Team, 2015. R: A Language and Environment for Statistical Computing. R Foundation for Statistical Computing, Vienna, Austria (Available at: http://www.R-project.org).

Raphael, J.P.A., Calonego, J.C., Milori, D.M.B.P., Rosolem, C.A., 2016. Soil organic matter in crop rotations under no-till. Soil Till. Res. 155, 45-53.

Rasse, D., Rumpel, C., Dignac, M.-F., 2005. Is soil carbon mostly root carbon? Mechanisms for a specific stabilisation. Plant Soil 269, 341-356.

Robertson, F.A., Thorburn, P.J., 2007. Management of sugarcane harvest residues: consequences for soil carbon and nitrogen. Aust. J. Soil Res. 45, 13-23.

Ronquim, C.C., 2007. Dinâmica Espaço Temporal Do Carbono Aprisionado Na Fitomassa Dos Agroecossistemas Do Nordeste Do Estado De São Paulo. Embrapa Monitoramento por Satélite, Campinas/SP (Documentos 63, p. 52, [cited 2016 November 28]. Available at: http://ainfo.cnptia.embrapa.br/digital/bitstream/ CNPM/2108/1/doc63_carbono_nesp.pdf).

Roscoe, R., Buurman, P., Velthorst, E.J., Pereira, J.A.A., 2000. Effects of fire on soil organic matter in a cerrado sensu-stricto from Southeast Brazil as revealed by changes in $813 \mathrm{C}$. Geoderma 95, 141-160.

Rossi, C.Q., Pereira, M.G., Loss, A., Gazolla, P.R., Perin, A., dos Anjos, L.H.C., 2013. Changes in soil $C$ and $N$ distribution assessed by natural $\delta 13 C$ and $\delta 15 \mathrm{~N}$ abundance in a chronosequence of sugarcane crops managed with pre-harvest burning in a Cerrado area of Goiás. Brazil. Agric. Ecosyst. Environ. 170, 36-44.
Santos, C.H., Romano, R.A., Nicolodelli, G., Carvalho, C.M., Villas-Boas, P.R., MartinNeto, L., Montes, C.R., Melfi, A.J., Milori, D.M.B.P., 2015. Performance evaluation of a portable laser-Induced fluorescence spectroscopy system for the assessment of the humification degree of the soil organic matter. J. Braz. Chem. Soc. 26, 775-783.

Schimel, D.S., Braswell, B.H., Holland, E.A., McKeown, R., Ojima, D.S., Painter, T.H., Parton, W.J., Townsend, A.R., 1994. Climatic, edaphic, and biotic controls over storage and turnover of carbon in soils. Glob. Biogeochem. Cycles 8, 279-293.

Seabra, J.E.A., Macedo, I.C., Chum, H.L., Faroni, C.E., Sarto, C.A., 2011. Life cycle assessment of Brazilian sugarcane products: GHG emissions and energy use. Biofuels Bioprod. Bioref. 5, 519-532.

Searchinger, T., Heimlich, R., Houghton, R.A., Dong, F., Elobeid, A., 2008. Use of U.S. croplands for biofuels increases greenhouse gases through emissions from land-use change. Science 319, 1238-1240.

Segnini, A., Carvalho, J.L.N., Bolonhezi, D., Milori, D.M.B.P., Silva, W.T.L., Simões, M.L. Cantarella, H., Maria, I.C., Martin-Neto, L., 2013. Carbon stock and humification index of organic matter affected by sugarcane straw and soil management. Sci. Agric. 70, 321-326.

Siles, P., Harmand, J.-M., Vaast, P., 2010. Effects of Inga densiflora on the microclimate of coffee (Coffea arabica L.) and overall biomass under optimal growing conditions in Costa Rica. Agrofor. Syst. 78, 269-286.

Silva-Olaya, A.M., Cerri, C.E.P., La Scala, N., Dias, C.T.S., Cerri, C.C., 2013. Carbon dioxide emissions under different soil tillage systems in mechanically harvested sugarcane. Environ. Res. Lett. 8, 015014.

Silveira, A.M., Victoria, R.L., Ballester, M.V., Camargo, P.B., Martinelli, L.A., Piccolo, M. C., 2000. Simulação dos efeitos das mudanças do uso da terra na dinâmica de carbono no solo na bacia do rio Piracicaba. Pesq. Agropec. Bras. 35, 389-399.

Six, J., Elliott, E.T., Paustian, K., 1999. Aggregate and soil organic matter dynamics under conventional and no-tillage systems. Soil Sci. Soc. Am. J. 63, 1350-1358.

Soil Survey Staff, 2010. Keys to Soil Taxonomy, 11 th ed. United States Department of Agriculture-Natural Resources Conservation Service, Washington, DC.

Thornthwaite, C.W., 1948. An approach toward a rational classification of climate. Geogr. Rev. 38, 55-94.

Tivet, F., de Moraes Sa, J.C., Lal, R., Milori, D.M.B.P., Briedis, C., Letourmy, P., Pinheiro, L.A., Borszowskei, P.R., da Cruz Hartman, D., 2013. Assessing humification and organic C compounds by laser-induced fluorescence and FTIR spectroscopies under conventional and no-till management in Brazilian Oxisols. Geoderma 207-208, 71-81. 